ELECTRIC MOTOR

MODEL REPAIR SPECIFICATIONS

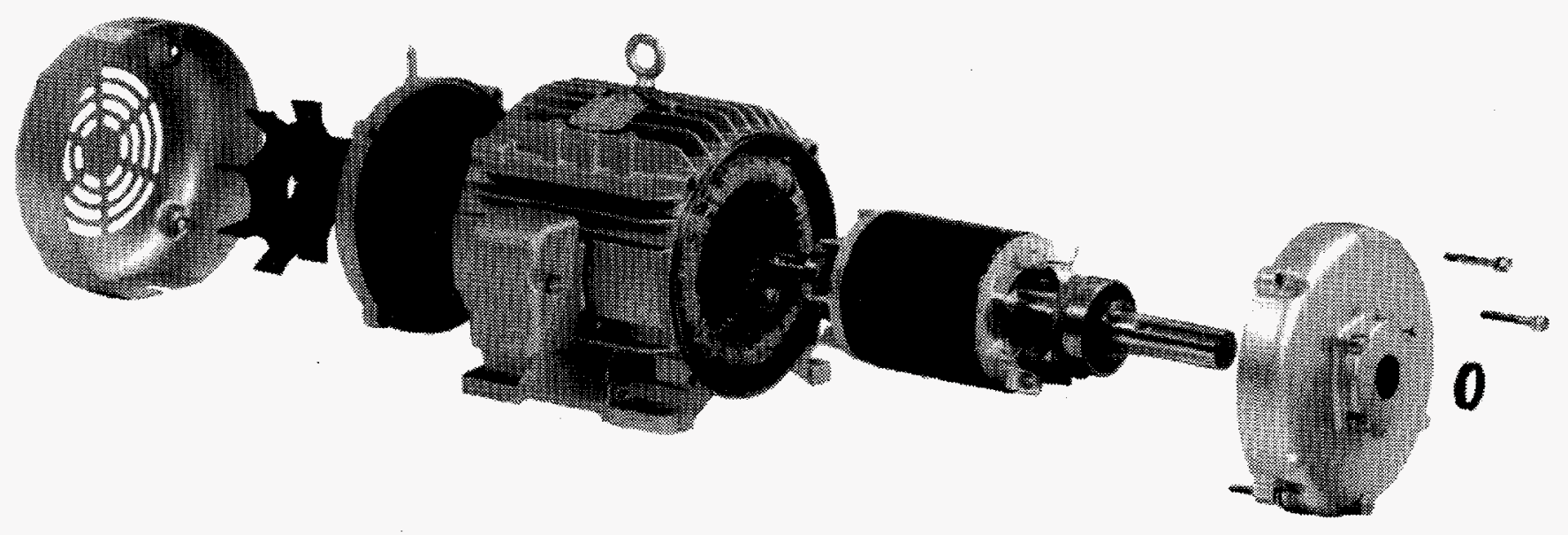

METRIBUTION OF THIS DOCUMENT IS UNLIMITED 

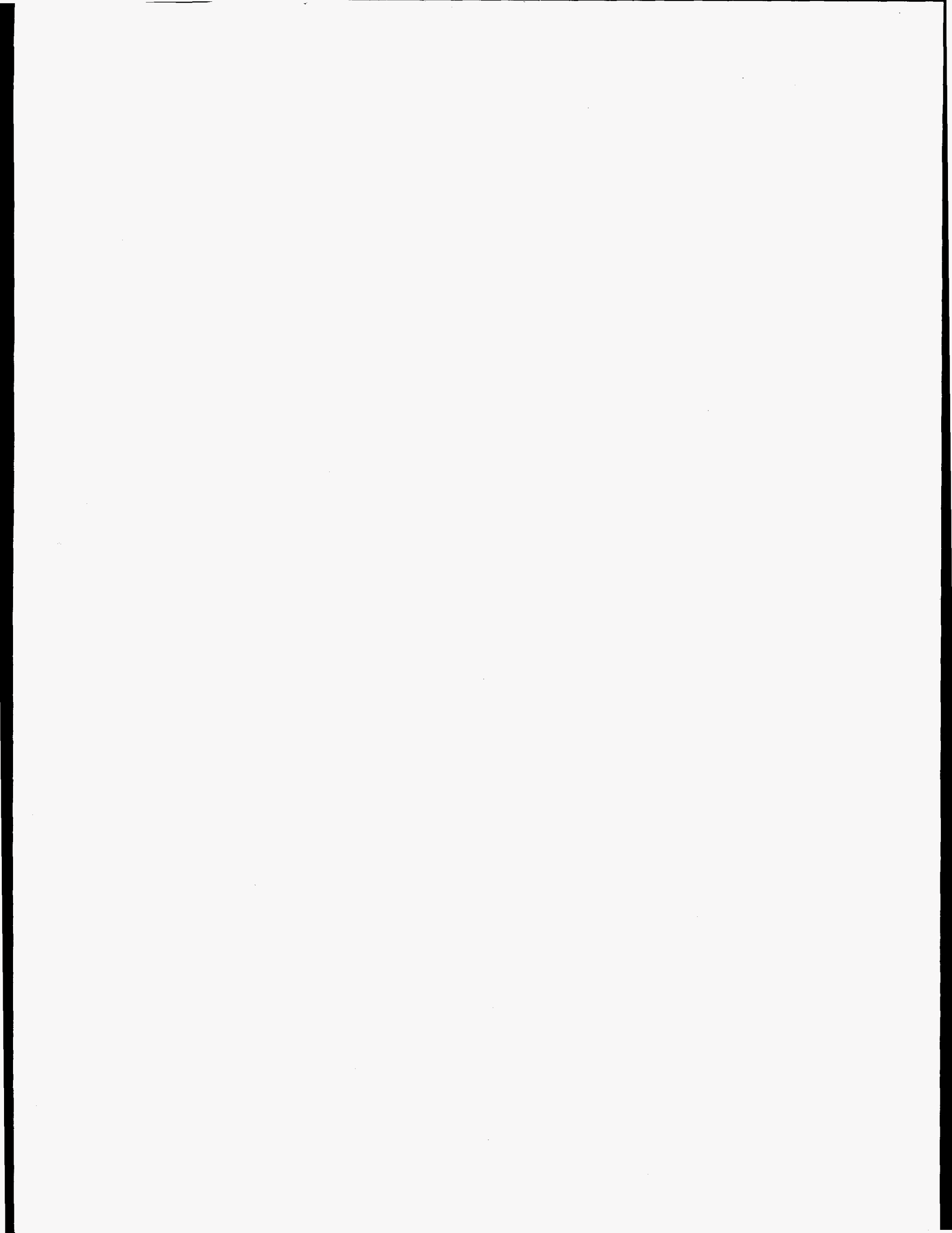


\section{Electric Motor Model Repair Specifications}

Compiled by:

Washington State Energy Office

November 19, 1994

Sponsored by:

Electric Power Research Institute Bonneville Power Administration United States Department of Energy 


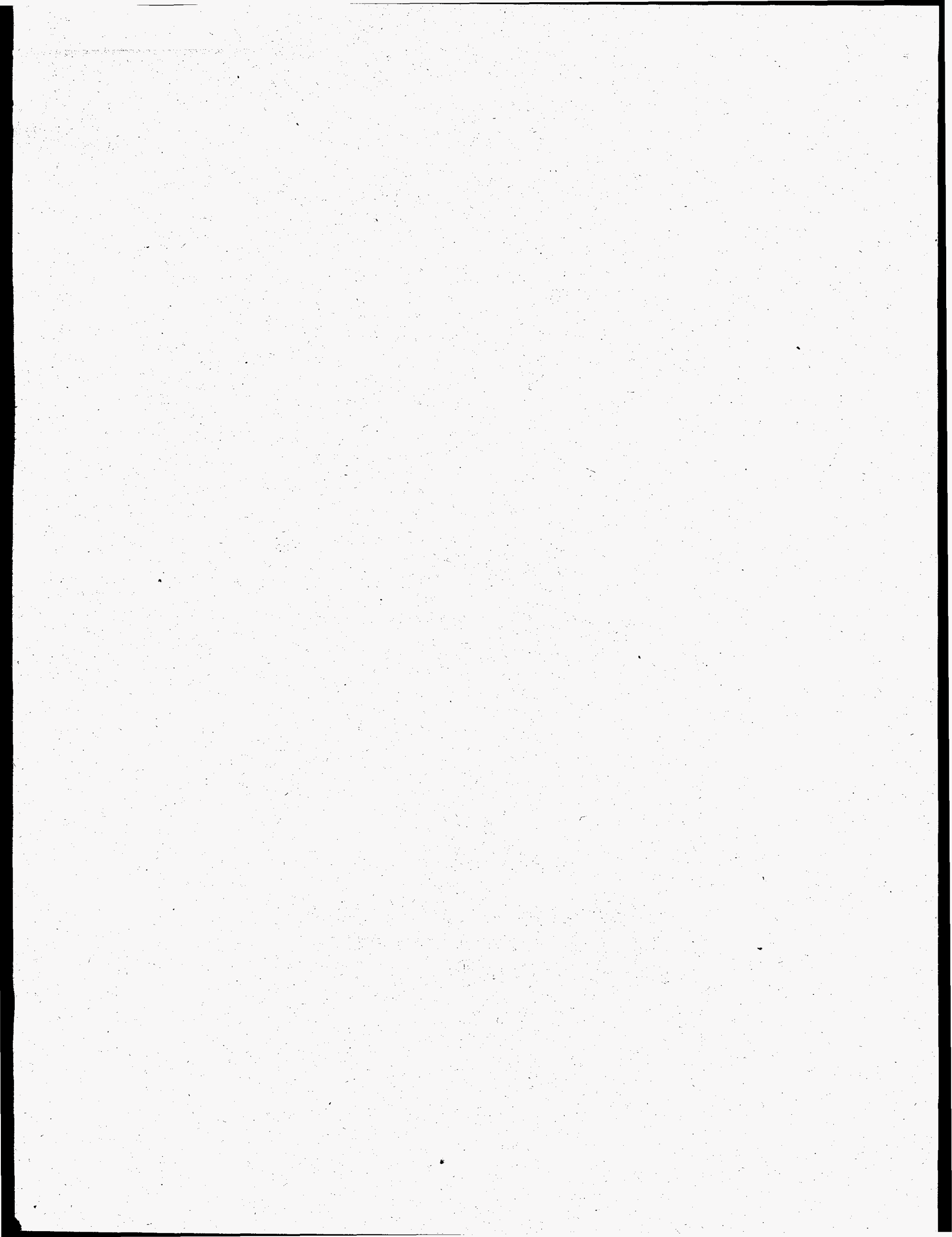




\section{BPA Report Summary}

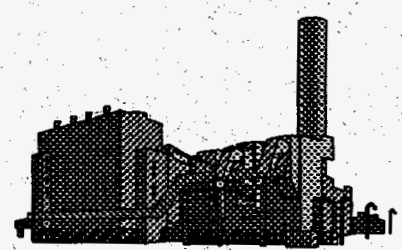

Industrial Technology

TITLE

ELECTRIC MOTOR

MODEL REPAIR SPECIFICATIONS

SUMMARY

These Model Repair Specifications list the minimum requirements for the repair and overhaul of polphase AC squirrel cage induction motors. All power ranges, voltages and speeds of squirrel cage motors are covered.

BPA

PERSPECTIVE

This R\&D project is one of a number of activities which support BPA's Market Transformation efforts. Market Transformation is a strategic effort initiated by BPA to induce lasting structural or behavioral changes in the market that result in the adoption and penetration of energy efficient technologies and practices

OBJECTIVE

To develop a set of Model Repair Specifications to help achieve a consistent, high quality diagnosis, repair and/or overhaul of a motor, and to return it to good operating condition with a minimum of delay and cost.

This objective is part of a broader goal to achieve a more energy efficient population of motors through appropriate selection of high efficiency new motors and improvements in repair.

PROJECT MANAGER
Craig Wohlgemuth, P.E.

Technical Assessment/R\&D-MPMT

Bonneville Power Administration

P.O. Box 3621

Portland, OR 97208

(503) 230-3044 
ORDERING INFORMATION

Report Number: DOE/BP-2748

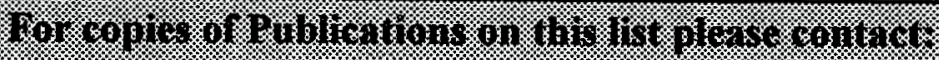

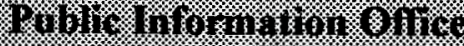

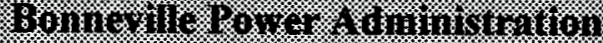

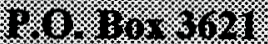

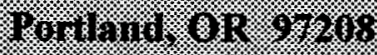

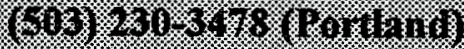

01

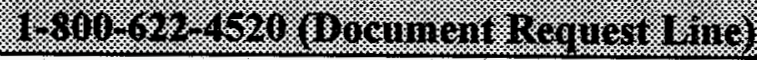




\section{Contents}

1.0 Introduction

1.1 Scope

1.2 Intent

1.3 Reference Documents

1.4 Hazardous Locations

1.5 Definitions

1.6 General

2.0 Repair Procedures

2.1 Documentation

2.2 Incoming Inspection

2.3 Dismantling

2.4 Vertical Motors

2.5 Winding Removal

2.6 Core Preparation

2.7 Random Rewinds

2.8 Form Rewinds

2.9. Routine Overhauls

2.10 Rotor Rest and Repair

2.11 Shaft Repair

2.12 Anti-Friction Bearings

2.13 Babbitt Bearings

2.14 End Brackets

2.15 Other Devices

2.16 Balancing

2.17 Reassembly

2.18 Final Tests

3.0 Quality Control $\quad 22$

3.1 Measuring Instruments $\quad 22$

3.2 Materials $\quad 22$

3.3 Tests and Inspection During Work _... 23

3.4 Final Inspection and Test $\quad 23$

3.5 Personnel 24

4.0 Documentation $\quad \cdots \quad 24$

4.1 Personnel 24

4.2 Repairer's Quality Record $\quad 24$

5.0 Repair Shop Evaluation $\quad 24$

5.1 Inspection 24

Appendix A $\quad A-1$

Appendix B $\quad$ B-1 

(1)

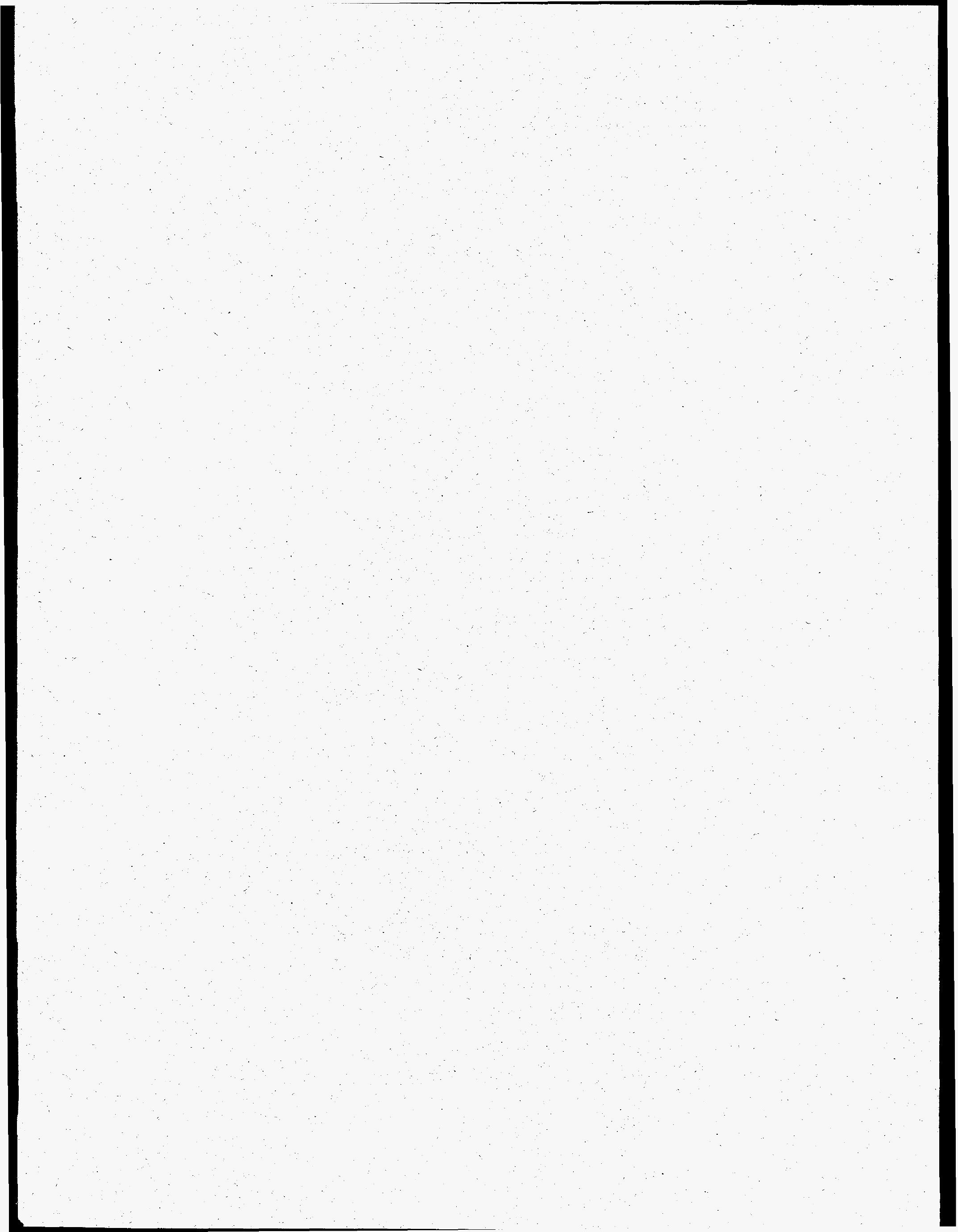




\subsection{INTRODUCTION}

1.1 SCOPE

1.2 INTENT

These Model Repair Specifications list the minimum requirements for the repair and overhaul of polyphase $\mathrm{AC}$ squirrel cage induction motors which are sent for repair. All power ranges, voltages and speeds of squirrel cage motors are covered.

The intent of these Model Repair Specifications is to achieve a consistent, high quality diagnosis, repair and/or overhaul to a motor, and to return it to good operating condition with a minimum of delay and cost. Not all portions of these Model Repair Specifications apply to all work.

Not all repair situations can be covered in these Model Repair Specifications. In the absence of specific instructions, the requirement shall be to restore the motor to original or better condition.

\subsection{REFERENCE DOCUMENTS}

The references to be used in conjunction with these Model Repair Specifications are the latest editions of the following:

UL UL674 Electric Motors and Generators For Use In Hazardous

EASA Standards For The Repair of Electrical Apparatus

IEEE IEEE Std. 43, Recommended Practice for Testing Insulation Resistance of Rotating Machinery

IEEE Std. 112, IEEE Standard Test Procedure for Polyphase Induction Motors and Generators

IEEE Std. 522, IEEE Guide for Testing Tum-to Turn Insulation on Form-Wound Stator Coils for Alternating-Current Rotating Electric Machines - For Trial Use

NEMA

NEMA Std. MG-1, Motors and Generators

ABMA

ABMA Std. 7, Shaft and Housing Fits for Metric Radial Ball and Roller Bearings

\subsection{HAZARDOUS LOCATIONS}

Motors intended for use in hazardous locations will have a nameplate to that effect. The repair work shall be done in a facility which has been certified by the Underwriters Laboratories to meet the requirements of UL674 Qualification of Facilities Engaged in the Repair of Electric Motors and Generators for use in Hazardous Locations. If the explosion-proof characteristics of the motor are not to be maintained, then the nameplate shall be altered to reflect this, and the motor will no longer be considered suitable for use in hazardous areas. 


\subsection{DEFINITIONS Lift}

Purchaser

Records

Repairer

1.6 GENERAL
Lift on a vertical motor is the maximum upward shaft movement possible from the rest position of the shaft at room temperature. It is measured by placing the assembled motor in the vertical position on a stand with no additional parts, such as couplings, on the shaft. A dial gauge is used to measure the total movement from the lower position to the upper position in respect to the frame, when the shaft is raised by means that are appropriate to the size of the motor.

Purchaser shall mean the customer requesting services to which these Specifications are applicable.

Records shall mean information recorded and maintained in the shop's files/computer for ten years or as otherwise agreed. A copy shall be provided to the client with the repaired or inspected motor.

Repairer shall mean the person(s) or company(ies) carrying out the work as specified in these Specifications.

\subsubsection{Unavoidable Degradation}

During the course of repair, if any damage is found which cannot be fully repaired, the purchaser's approval is required before proceeding. Likewise, if any repair is indicated which may result in a permanent degradation of efficiency of other performance parameter, the purchaser's approval is required before proceeding.

\subsubsection{Operating Environment}

The motor will operate in an environment where the following materials are present (e.g., salt spray, coal dust, certain corrosive chemicals, etc.) No repair methods or materials may be used which are more vulnerable to these materials than the original motor.

\subsubsection{If Powered by an Inverter}

If the motor is powered by a pulse-width modulated inverter, windings shall be sufficiently insulated and supported to withstand this type of power supply. The purchaser shall be notified if line inductors or other external protection are deemed more cost effective than reinforcing the motor.

\subsubsection{Subcontracted Work}

If any work is to be subcontracted (e.g., rotor balancing) or any subassemblies (e.g., formed coils) are to be provided by outside sources, the purchaser shall be advised of the providers of these parts/services as soon as it is known they are required. 


\subsection{REPAIR PROCEDURES}

\subsection{DOCUMENTATION}

2.1.1 Repair Form The motor will be accompanied by a Motor Repair Form from the purchaser which will list the perceived problems, the operating environment, the urgency of the repair, past problems where applicable, the required repair, cost constraints, missing parts and the person within the purchaser's organization to be contacted about the repair. This form shall be used as a guide for the repair. A sample is included in Appendix A. During repair, actions and findings will be recorded on a Repairer's Quality Record. It, shall also contain records of all the work done, problems noted, checks and measurements taken during the work, repairs carried out and the final tests conducted prior to shipping. Requirements for the work, checks and tests are listed in following sections. A sample is included in Appendix B.

2.1.2 Extra Work If tests and inspection indicate that there are problems beyond the initial scope of the listed repair, then the designated person shall be contacted and given a description of the problems, plus an estimate of their effect on delivery and costs.

2.1.3 File

The repairer will keep a copy of the Motor Repair Form and Repairer's Quality Record in the file for the particular job.

\subsection{INCOMING INSPECTION}

On receipt of the motor and after reading the repair form, the repairer shall do the initial tests set out below, plus any other tests, indicated by the form.

2.2.1 Intent

The intent of the tests shall be to determine and record the probable cause of failure, if any, and to determine what work is required.

2.2.2 Visual

A visual inspection shall be made to assess the general condition of the outside of the motor for cracks, broken welds and missing parts."

\subsubsection{Insulation to Ground}

An insulation resistance test to ground shall be performed, at a voltage suitable for the motor's voltage rating and the apparent condition of the motor. The insulation need not be tested if it is obviously defective. The testing shall be as follows:

- The initial test voltage shall not exceed 1,000 volts DC for insulation rated up to 1,000 volts and shall not exceed 1.5 times the insulation rating for insulation rated over 1,000 volts.

- For motors where there are more than one winding, the insulation shall also be tested between windings, at the test voltage appropriate to the lower voltage winding, with other windings grounded.

- The duration of the insulation test shall be one minute. The temperature and the humidity shall be recorded. 
The shaft shall be manually rotated, to check for any obvious problems with the bearings or shaft. If the motor has sleeve bearings, this test may be omitted, but the bearings and journals shall be checked later.

2.2.5 No Load Run

If possible, the motor shall be run on no load, at nameplate voltage and checked for balanced currents and vibration. The readings shall be noted in the job file.

\subsection{DISMANTLING}

\subsubsection{Identify Problem}

After the incoming inspection, the motor shall be dismantled to the extent needed to either fully identify or repair the problem, or to do the specified overhaul.

\subsubsection{Markings End brackets and frames shall be clearly match-marked.}

2.3.3 Parts Storage Bolts and small parts shall be stored in dedicated containers and parts from other jobs shall not be kept with them.

\subsubsection{Insulated Bearings}

If the motor has insulated bearings, note which, if any, have the insulation deliberately bridged. The insulation resistance of each insulated bearing shall be at least one megohm with a 500 volt test.

2.3.5 Dowels $\quad \ldots \quad$ If dowels or fitted bolts are used to ensure accurate fits, the location of these pieces shall be identified.

2.3.6 Explosion Proof For motors certified for hazardous locations, extra care shall be taken to ensure that joints and flame paths are not damaged during the work. If damage requiring other than normal repair is found, purchaser shall be notified before proceeding with repair.

2.3.7 Heavy Shaft

For horizontal motors where the shaft rotor assembly is too heavy to be removed easily by hand, one or two cranes shall be used to move the shaft, with a close fitting pipe installed over one end of the shaft to act as a shaft extension. Attention shall be paid to the following:

- Care shall be taken that the slings do not damage the bearing surfaces or the rotor.

- Under no circumstances shall the stator windings be touched by any of the parts being moved.

\subsection{VERTICAL MOTORS}

Vertical motors shall be dismantled according to the manufacturer's instruction book. The assembly of vertical motors is critical. Particular attention shall be paid to, and records kept of: 
- The amount of rotor lift;

- The make and types of bearings, particularly the thrust bearings;

- The arrangement of the thrust and guide bearings, including specially ground mating surfaces;

- The axial and radial clearances (fit) to the shaft and housing;

- The method of lubrication of both upper and lower bearings;

- The method of bearing insulation, if any, and

- Any other particular features of the motor configuration.

\subsection{WINDING REMOVAL}

2.5.1 General

2.5.2 Take Data

2.5.3 Core Loss

2.5.4 Burn Out
For motors that are to be rewound, the core shall be stripped, cleaned, tested and repaired.

Winding data shall be obtained to permit coil manufacture of either random or formed coils.

A core loss test shall be done on all stators both before and after stripping and iron repair, to check for damaged interlaminar insulation. The tests shall be done at a flux density of 85,000 lines per square inch rms. Exciting current and watts loss shall be recorded each time, as well as a physical check carried out for hot spots. If data from previous tests are available, the results shall be compared. Testing at other flux densities may be done if original data is available.

If any areas are more than $15^{\circ} \mathrm{C}$ above the average after 10 minutes, or losses are excessive overall either before or after stripping, the situation shall be discussed with the purchaser before proceeding further. For a core without any hot spots, the losses after stripping shall not be more than 110 percent of the pre-strip losses. To avoid misleading results, the second core loss test should not be done until the core has been cleaned and dried.

The winding shall be burned out in a controlled temperature burnout oven where the temperature is limited to $345^{\circ} \mathrm{C}\left(650^{\circ} \mathrm{F}\right)$ by means of fuel control and supplementary (water spray) cooling. If a higher temperature is deemed necessary, repairer shall reference communication or documentation from the motor manufacturer indicating that the core iron can safely withstand the temperature.

\subsubsection{Aluminum Frame}

Frames may be chemically stripped if burnout facilities are not available. Other methods of stripping may only be used with purchaser approval. 


\subsection{CORE PREPARATION}

2.6.1 Cleaning

2.6.2 Iron Repair
The stripped core shall be cleaned of all foreign material, such as insulation debris, and dried.

All obvious iron damage, plus any problems indicated by the core loss tests, shall be repaired, as shall any frame damage.

\subsubsection{Method of Repair}

The method of repair to damaged cores shall be discussed with purchaser and shall be chosen from the following:

- Grinding Selective grinding with a small sharp power tool;

- Machining Machining with a boring mill or comparable machine, taking care that the laminations are cut cleanly and not burred over (care shall be taken, especially on two and four pole motors, to maintain a constant air gap; on all motors, the combined rotor and stator machining shall not increase the total air gap by more than 20 percent.);

- Spray between laminates Separating laminations and reinsulating with spray-on interlaminar insulation;

- Mica between laminations Inserting split mica between the laminations; and,

- Restacking Restacking, with deburred laminations and new interlaminar insulation.

- Winding left in Iron damage repairs where the winding is to be left in the motor are very difficult. A detailed plan shall be proposed to the purchaser before work is commenced, and the purchaser shall be informed of progress.

2.6.4 Core Loss Test A final core loss test shall be done as described in sub-section 2.5.3.

\subsection{RANDOM REWINDS}

2.7.1 Winding Details The total cross sectional area of a turn, the turns per coil, the span and connection of the coils shall not be changed without authorization from engineering and purchaser.

2.7.2 Thermal Class Class $F$ or higher grade materials shall be used throughout. Windings which were originally Class $\mathrm{H}$ shall be replaced with a Class $\mathrm{H}$ rewind. 
2.7.3 Sensors

Temperature sensing devices shall be replaced with devices comparable to those previously used.

\subsubsection{Explosion Proof}

If the temperature class of the insulation of an explosion-proof motor has been increased, a temperature sensor shall be installed to monitor and limit the motor surface temperature to the original maximum external temperature. The motor shall be tagged with a warning to the operator that to maintain the hazardous area classification, the sensor must be connected to shut down the motor.

\subsubsection{Insulation Materials}

Insulation shall include, as a minimum, the following components:

- Turn Insulation Multiple build coating turn insulation of polyamide, polyimide or a combination of both over polyester, or equivalent;

- Slot Liner Slot liner extending at least one quarter inch past each end of the slot;

- Separator Center strip or separator between the top and bottom coil sides in a slot;

- Wedge A top piece to hold the coils in the slot (where needed, a filling piece shall be used to make up any extra space in the slot); and,

- Phase Barriers Phase barriers between end turns of different phases (these shall be trimmed to permit clear air flow).

\subsubsection{End Turns}

2.7.7 Connections

\subsubsection{Surge Test}

The end turns shall be fully compacted so that there are no loose wires. Both sets of end turns, plus leads and jumpers shall be laced tightly together so that each turn is tied securely to the two adjacent coils.

All connections shall be brazed with materials that will not be subject to corrosion in the specified operating environment. They shall have no sharp edges and shall be insulated with slip-on sleeving.

Before impregnation, the winding shall be given a test to verify that there are no wrong connections or shorted turns. This may be a Surge Comparison Test or a high potential and winding resistance test. Voltage used shall be as indicated in EASA Standards for the Repair of Electrical Apparatus or other standards approved by purchaser. Any defects shall be corrected and retested before impregnating. Test results shall be recorded in the repairer's job record sheet. 
2.7.9 Impregnation The rewound stator shall be impregnated in one of the following ways:

- Dip-and-bake Double dip-and-bake cycle using resin or varnish and a temperature controlled bake oven (baking times and temperatures shall be recorded in the repairer's job record sheet.);

- Trickle A trickle epoxy or polyester treatment where the resin is poured into the end turns and slots of a vertical stator which has been heated with controlled electric current to assist in curing the resin; and,

- VPI Vacuum Pressure Impregnation (VPI) treatment.

\subsection{FORM REWINDS}

\subsubsection{Material}

2.8.2 Process

2.8.3 Coils

2.8.4 Stranding
All materials used shall be rated temperature Class $\mathrm{F}$ or higher.

The post winding VPI method using polyester or epoxy resin is preferred over other methods of impregnation of the winding as described in sub-section 2.8.17.

New coils shall be suitable for use with the impregnation system in use. They shall be insulated with material that will permit the resin to fully penetrate all the insulation with the pressures used. They shall all be of consistent shape.

Dimensions shall be such as to permit insertion into the slots with a minimum of force.

Changing the strand dimensions is permitted, when the proper size is not available within the required time, but the total cross-sectional area of copper shall not be diminished. The new stranding must not permit buckling during the coil forming and handling processes. The modified design shall be approved by engineering. If the total cross-sectional area is to be increased, the client shall be notified regarding magnitude of possible increased inrush and locked rotor current.

2.8.5 Turn Insulation The turn insulation shall be such that when inserted in the core, a single unimpregnated coil shall be able to withstand, from lead-to-lead, a voltage surge ranging from 350 volts times the number of turns in the coil to a maximum value of two times the crest value of the motor's line-to neutral voltage. This is discussed in more detail in IEEE Std. 522. Example: For a motor rated at 4,000 volts line-to-line with nine turns per coil, the test voltage would not exceed 6,500 volts.

2.8.6 Ground Wall Ground wall insulation shall be mica based with a protective layer over the insulation to prevent insulation damage during installation.

The ground wall shall be capable, before impregnation, of withstanding an AC test voltage of the nominal line-to-line motor voltage for one minute. If an AC tester is not available, a 1.67 multiplier shall be applied to the $\mathrm{AC}$ test voltage to obtain the equivalent $\mathrm{DC}$ test voltage. 


\subsubsection{Anti-Corona Paint}

Anti-corona paint shall be applied in and beyond the slot portion of coils in motors which originally had anti-corona paint. Unless otherwise approved, the materials and methods shall be as originally supplied.

2.8.8 Slot Liners

2.8.9 Insertion

2.8.10 Packing

2.8.11 Wedges

2.8.12 RTDs

2.8.13 Tests
Slot liners shall be used on coils without anti-corona paint if they were previously used on the motor or if there is room in the slot. They shall extend at least three eight's. inch beyond the iron at each end. Side and bottom packing shall be used to ensure a snug fit in the slot. With prior approval, slot sized coils may be used without slot liners provided the extra insulation is built into the coils.

Care shall be taken to ensure the coils are not damaged during insertion, especially in the area near the end of the slots. Excessive distortion of the coils will be avoided by leaving sufficient coils partially removed from the slots as the final coils are inserted and by waxing or heating the coil to make insertion easier.

The top, middle and bottom packing shall be sufficient to ensure a snug fit for the wedge.

The wedging, if not continuous, shall be placed in similar positions to the original factory wedging. Motors which had magnetic wedges when originally built, shall have magnetic wedges installed to maintain the performance characteristics.

Resistance Temperature Detectors (RTDs) shall be installed as follows:

- Number Characteristics Unless otherwise specified, they shall be the same number and have the same characteristics as the original detectors.

- Stick Type They shall be of the stick type.

- Dimensions They shall be at least six millimeters wide and the length shall be approximately 50 percent of the slot length. They shall be inserted in equally-spaced slots, between upper and lower coils, with packing filling the gap where the detector is not located.

- Location The detectors shall be placed in the center of the slot width and in the expected hottest portion of the slot length. As far as possible, they shall be in intimate contact with the upper and lower coils.

Each detector shall be installed and its leads brought out so that the detector is effectively protected from contact with the cooling air.

Before connecting, the entire dried winding shall be subjected to a one minute Hipot test of the voltage listed in sub-section 2.8 .6 and the leakage at the end of the test shall be noted. RTDs shall be grounded during this test. 


\subsubsection{Bracing}

Each coil shall be subjected to a surge voltage at the level specified in subsection 2.8.5.

Any coils failing either of these two tests shall be either replaced or repaired and the test repeated.

The end turns shall be braced at the points of the original winding. The acceptable methods of coil support shall be:

- Coil support rings, which shall be either fixed or floating, as in the original winding, and shall be as strong as the original rings. (Magnetic material shall not be used in the rings. They shall be insulated, or made of insulating material and, if necessary, packing shall be put between the ring and the coil before tying the coil to the ring. Regardless of the practice originally followed, each individual coil shall be tied to all support rings.)

- Dacron felt spacers between the coils. (The spacers shall be of dacron felt, folded over at least once so that they are compressed during insertion. They shall be at least as deep as the coil height. Spacers cut from pre-cured sheet material shall not be used alone.)

- An epoxy loaded rope tied inside the knuckle, of each coil and overlapping through two knuckles. (The rope shall either be new, or shall have been kept refrigerated before use.)

The twine used for tying shall be compatible with coils and shall not cause abrasion under movement.

All connections shall be brazed.

Before insulating, the joints shall be smoothed off to avoid any sharp points which may cause corona or puncture the insulation.

Joint Insulation Joint insulation shall be compatible with the coils and resin, and shall be comprised of the following:

- At least one thickness of flexible tape over the metal (For VPI processes, the tape shall permit resin entry);

- At least one thickness of glass/mica compound tape for every thousand volts of motor rating;

- A layer of protective tape overall; or,

- Other method as approved provided it gives equal insulation capabilities.

Jumpers and Leads Jumpers and leads shall be tied to the coils and to each other wherever they come close or in contact. Dacron felt spacers shall be used where needed, to make the whole structure more rigid. Leads are discussed in sub-section 2.15.3. 


\subsubsection{Vacuum Pressure Impregnation}

The resin used with the VPI system shall be 100 percent reactive epoxy or polyester, with a viscosity at operating temperature, low enough to fully penetrate the tape layers and a gel time fast enough to minimize drainage. It shall be compatible with the coil insulating materials.

- Resin Sample To ensure quality, a sample of the resin shall have been taken and tested satisfactorily within two months before the motor is impregnated. The results of the resin tests shall be kept on file and a copy of the most recent test kept in the Job Quality Record (see Appendix B).

- Vacuum/Pressure Levels The vacuum portion of the cycle level shall be at $10 \mathrm{~mm}$ of mercury or less, and the pressure portion of the cycle shall be at 95 psi or greater. The duration of the cycles shall be sufficient to achieve full impregnation with no voids.

- Spare Coil A spare coil shall be purchased with each coil order and run through the impregnation process, with one side in a fabricated dummy slot, at the same time as the main winding. A portion of this spare coil shall be shipped with the motor for later use while the other portion shall be used for internal quality control checks. If the spare coil is used to replace one which fails insulation testing, then the coil which is removed from the stator may be used for the impregnation test.

- Two Cycles Each winding will go through at least two vacuum pressure cycles with oven curing after each treatment.

\subsubsection{Non-VPI Systems}

Non-VPI systems may be used with specific approval: The methods of inserting, wedging, testing, connecting and bracing shall be as described in the relevant preceding sections except that for fully precured coils the ground wall AC test voltage shall be twice the nominal line-to-line terminal voltage plus 1,000 volts, with a DC conversion multiplier of 1.67 .

The coils shall be pressed to shape in the slot section both before and after ground wall application and impregnation.

The coils also shall use the following:

- VPI Coils A prewinding vacuum pressure impregnation system;

- Loaded Tape Loaded tape systems which are cured during processing; or,

- Dip-and-Bake Multiple dip-and-bake cycles in Class F varnish. 


\subsection{ROUTINE OVERHAULS}

2.9.1 Testing

\subsubsection{Cleaning}

After dismantling, the following procedure shall be followed:

- Winding and cooling ducts shall be cleaned, dried and inspected.

- Winding insulation resistance shall be tested at 1,000 volts DC.

- The duration of the test shall be one minute for random windings and 10 minutes for form windings.

- For form wound windings, the readings shall be recorded every minute, and the polarization index (ratio of 10 minute to one minute resistance) calculated.

- For random wound windings, the minimum acceptable level after one minute, corrected to a $40^{\circ} \mathrm{C}$ reference temperature by the insulation resistance correction chart shown in Appendix C, is 100 megohms. Levels less than 100 megohms shall be discussed with the purchaser.

- For form wound windings, the minimum acceptable level after one minute, corrected to a $40^{\circ} \mathrm{C}$ reference temperature, is 250 megohms. Levels less than this shall be discussed with the purchaser.

- For form wound windings, the polarization index shall be at least two. Levels less than this shall be discussed with the purchaser.

- If satisfactory levels are not attained, the winding shall be recleaned and dried thoroughly at a temperature not exceeding $100^{\circ} \mathrm{C}\left(212^{\circ} \mathrm{F}\right)$, and then retested.

- For form windings, a successful insulation resistance test shall be followed by a withstand test for one minute at a level of two times the line-to-line voltage plus $1,000 \mathrm{~V} \mathrm{DC}$, or 70 percent of this level $\mathrm{AC}$.

- After successful insulation resistance to ground has been achieved, the winding shall be given a high potential or surge comparison test. Voltage level used shall be as indicated in EASA Standards for the Repair of Electrical Apparatus or other standards approved by purchaser.

The components, including the stator windings, shall be cleaned with hot water and a suitable detergent after heavy deposits of dirt and grease have been removed mechanically.

If necessary, brushes shall be used to clean small passages in components.

Solvents shall not be used to clean insulation, but may be used on mechanical components of the motor. 
All components șhall be thoroughly dried at a temperature less than $100^{\circ} \mathrm{C}$ $\left(212^{\circ} \mathrm{F}\right)$, for as long as it takes to remove all signs of moisture. For windings, this will be indicated by the insulation resistance reaching a plateau after some hours of drying.

2.9.3 Repairs

After satisfactory insulation resistance has been attained, all loose or damaged wedges, slot sticks, coil supports etc., shall be replaced or repaired.

The winding shall then be given a dip-and-bake using a Class $\mathrm{F}$ or higher grade varnish. Immersion and baking times shall be sufficient to penetrate any cracks and give a sealed durable finish to the insulation. The repairer shall notify the purchaser if a dip-and-bake is undesirable.

If the winding originally had an anti-corona paint, the manufacturer's recommendations shall be followed for the varnish treatment.

2.9.4 Other

2.9.5 Reassembly
The routine overhaul of other parts of the motor shall return the parts to good condition.

\subsection{ROTOR TEST AND REPAIR}

2.10.1 Testing

All rotors shall be given a test for damaged bars, whether the motor is suspect in this area or not.

This test shall apply a stable single-phase voltage to the stator of the assembled motor while the shaft is slowly turned through at least one revolution. Any fluctuations of stator current in excess of 5 percent shall be investigated further.

Other methods may be used if it can be shown that they have a good record of detecting faults.

For motors where electrical or mechanical problems with the rotor are suspected, more sophisticated tests shall be used. These include:

- Measuring watts and power factor on single phase tests;

- Growler tests;

- Analysis of the amperes, volts and vibration of a loaded motor;

- Physical examination;

- Ultrasonic examination of the bars and end rings; and,

- Core loss tests. 


\subsubsection{Fabricated Cage Repair}

Since repair of squirrel cages can be expensive, no work shall be done in this area without approval.

2.10.3 Swaging

If inspection reveals that the bars are merely loose in the cage and there are no cracked or broken bars or joints, the bars shall be fixed firmly in the slots by swaging each bar at a minimum of three points along the slot. The bar shall be deformed so that it fits snugly in the slot by indentation of the top surface of the bar.

It is understood that with some forms of rotor construction, this method may not be practical, and in these cases other methods may be proposed for purchaser approval.

2.10.4 Joint Repair If it is only necessary to repair some joints, the end ring shall be removed, all mating surfaces shall be cleaned and the joints remade as described in subsection 2.10.6. Care shall be taken not to damage any other components during the dismantling.

The length of bar extending from the rotor core shall not be changed without specific approval.

\subsubsection{Cage Replacement}

For cage replacement, the conductive, metallurgical and strength characteristics of both the bar and end ring materials shall be determined and equivalent materials used.

Since changing the rotor resistance has major effects on the motor performance, no change in resistance is permitted.

Any parts that are to be reused shall be cleaned and examined for defects.

The new bars shall be machined to be a snug fit in the slot (i.e., some force is required to push them into the slot).

2.10.6 Brazing The bars shall be brazed or welded to the end rings with material that is not subject to chemical attack by the contaminants listed by the purchaser on the Motor Repair Form for the particular motor.

Brazing shall be done as rapidly as possible in one continuous operation to minimize heating of rotor iron.

2.10.7 Testing

2.10.8 Balance
After fabrication, the joints shall be examined and tested by ultrasonic or comparable means, and the bars swaged in place.

The rotor shall be balanced to the tolerances listed in sub-section 2.16 of these Specifications. 
2.10.9 Cast Rotor Repair

A defective cast cage shall not be repaired without prior authorization from the purchaser.

The method of repair shall be to remove the old cage by chemical means, without damaging the laminations, followed by rebarring with extruded, aluminum bars and duplicate cast aluminum endrings using the methods described in sub-section 2.10 .5 to 2.10 .8 to give the same cage resistance as before.

\subsubsection{Iron Repairs}

Because of the costs involved, this work shall not be done without prior purchaser approval. If tests or observation indicate that the laminations have been damaged, they shall be repaired or replaced with new laminations. Care shall be taken to ensure a consistent air gap: the total of both stator and rotor machining shall not increase the air gap by more than 20 percent.

This shall be followed by balancing to the tolerances specified in sub-section 2.16.

\subsection{SHAFT REPAIR}

2.11.1 General

If information on the Motor Repair form, or any tests indicate that there may be a shaft problem, it shall be tested and repaired or replaced. If there is any risk or uncertainty in the proposed repair method, this shall be discussed with the purchaser prior to proceeding.

2.11.2 Requirements When the work is completed, the shaft shall meet the following criteria:

- Total Indicated Runout It shall be straight, with a Total Indicated Runout (TIR) when measured in V blocks, of no more than specified in the EASA Standards for the Repair of Electrical Apparatus or other standards approved by purchaser.

- No Cracks The shaft shall have no cracks. If ultrasonic, magnetic particle, dye penetrant or other testing methods are needed to verify this, they shall be documented in repair records.

- Straight The shaft shall be straight, parallel and undamaged at the bearing areas. If any measurable but acceptable deviation from this is noted, it shall be documented in repair records.

- Journal Repairs Journal repairs shall be by welding or plating, followed by machining and grinding. They shall return the shaft to the size specified by the anti-friction bearing manufacturer for the application, or to give the correct clearance, as listed in sub-section 2.13 for a babbitt bearing.

- Journal Runout The TIR in the journal area of a sleeve bearing motor shall not exceed $0.013 \mathrm{~mm}(.0005 \mathrm{in})$ when measured with the shaft supported in narrow $V$ blocks. 
- Fit to Rotor It shall be a tight fit to the rotor iron. If there is looseness, the shaft should be replaced. If the repairer believes that welding will give satisfactory results, this shall be approved by the purchaser.

- Shaft Material New shafts shall be machined from AISI Gr. C1045 hot rolled steel or equivalent. For special applications, the repair shop and the manufacturer will consult and report to purchaser.

- Tolerances In general; shaft dimension tolerances shall be within the limits specified in NEMA MG-1, Motors and Generators sections.

- Proximity Probes For motors with proximity probes, the area under the probes shall have mechanical runout less than $0.013 \mathrm{~mm}(.0005 \mathrm{in})$ and total electrical and mechanical runout less than $0.018 \mathrm{~mm}(.0007 \mathrm{in})$. Grinding and demagnetizing may be needed to achieve this.

\subsection{ANTI-FRICTION BEARINGS}

2.12.1 New Bearings Anti-friction bearings shall be replaced with the same type as originally used, unless otherwise approved by the purchaser. If the bearing type, size, sealing, shielding or configuration is changed, this shall be noted on the nameplate. If the original bearing race showed pitting from shaft current, the causes and remedy for this shall be discussed with purchaser. Purchaser reserves the right to specify the bearing manufacturer.

\subsubsection{Shielding, Sealing}

If the method of shielding, sealing or lubricating is to be changed, it shall be approved by the purchaser.

2.12.3 Clearance

2.12.4 Tolerances

2.12.5 Heating

2.12.6 Grease

2.12.7 Oil Mist
Unless otherwise specified by the manufacturer or purchaser, C3 clearance bearings shall be used for all bearings.

Fitting tolerances to the journals and housings shall be to the recommendations for electric motors found in ABMA Std. 7.

The bearing shall be heated, without use of direct flame, to approximately $182^{\circ} \mathrm{F}$ to permit it to be slid easily onto the shaft up to the shoulder.

Greasable bearings shall be lubricated as specified in the EASA Standards for the Repair of Electrical Apparatus or other standards approved by purchaser.

On motors which use oil mist bearing lubrication systems, care shall be taken to ensure the shaft seals are in good condition, and there are no blocked passages. 


\section{13 BABBITT BEARINGS}

2.13.1 Checks

\subsubsection{Repair}

\subsubsection{Rebabbitting}

When rebabbitting bearings, the following shall be observed:

- Centrifugal Casting Centrifugal casting shall be used with thorough cleaning and preparation of the backing metal.

- Lead Free The babbitt shall have high tin content and shall be lead free.

- Bond After initial machining, the bond of babbitt to backing metal shall be verified ultrasonically to be more than 80 percent.

- Machine The bearing shall be machined to the specified clearance, and oil grooves, RTD pockets and other features that were in the original bearing, duplicated.

- Check fit The bearing shall be checked for fit to the shaft by bluing and checking the contact pattern after assembly, rotation and dismantling of the bearing. The bearing shall be scraped and polished until a uniform contact pattern is achieved.

- Clearance Clearance shall be checked with a plastigage or equivalent method, to be within the specified range.

\subsubsection{Insulated Bearings}

Insulated bearings shall be tested per IEEE 112, section 9.4.3.

2.13.5 Oil Rings

Oil rings shall be round within $0.025 \mathrm{~mm}(.001 \mathrm{in})$ and shall have no rough edges. Replacement rings shall be machined from the same material as the original rings. 


\subsection{END BRACKETS}

2.14.1 Requirements End brackets should be snug fits to the stator frame. Worn dowel holes and rabbit fits shall be repaired.

2.14.2 Clearances

Clearances to the outer sections of anti-friction bearings shall be within the tolerances specified by ABMA Standard 7.

2.14.3 Repairs

Repairs to end brackets shall be by building up the metal and machining to size. Welding, plating and sleeving are the accepted methods.

Epoxies and other compounds shall not be used for locking bearings.

\subsection{OTHER DEVICES}

2.15.1 Fans Fans shall be checked for cracks and fit to the shaft or rotor.

Fans shall be firmly fixed to the shaft or rotor by the original factory method, unless there has been corrosion between dissimilar metals, in which case a new method shall be proposed to the purchaser. Welding to the shaft is not permitted.

Repairs to fans shall only be done with purchaser approval.

New fans shall be as supplied by the original manufacturer unless the design appears to be defective, in which case, purchaser and the repairer will discuss a new arrangement.

Fans used in motors for use in hazardous locations shall be made of material which will not cause sparking, either by impact or by build up of static electricity.

\subsubsection{Temperature Sensors}

Temperature sensors shall be installed in the motor as originally found or as otherwise specified by purchaser.

- Winding RTDs Winding RTDs are discussed in sub-section 2.8.12.

- Bearing RTDs Bearing RTDs shall be of the same type as those removed and shall be located to sense, as nearly as possible, the highest babbitt temperature. If the original bearing RTD was insulated, the replacement shall also be insulated.

- Thermistors Thermistors, thermocouples and other devices shall be as per the original and will usually be located in the end turns. 
Leads shall be flexible and multistranded, and have the same cross sectional area and temperature class as the original leads.

Main power and accessory leads shall be indelibly marked using the same marking systems as the incoming motor. If this is illegible, then the system described in NEMA MG-1, Motors and Generators, Section 2 shall be used and a notice describing the system attached to the terminal box. Every effort shall be made to keep the original direction of rotation.

Lugs, if used, shall be suited for the application and have all cable strands in the lug. No cable strands may be cut off or bent back to facilitate insertion in the lug.

If crimp lugs are used, the correct make and style of die shall be used for the particular lug, and the correct compression applied.

\subsubsection{Junction Boxes}

Junction boxes shall be returned to original condition. In particular, the following items must be confirmed:

- Missing bolts for both the cover and the motor-to-box joint shall be replaced.

- On motors certified for hazardous environments, the junction boxes shall be sealed off from the main body of the motor by a sealing compound.

- Damaged flanges shall be repaired. No paint or gaskets shall be left on the flanges of boxes for explosion-proof motors.

2.15.5 Space Heaters Space heaters shall be tested for insulation resistance for one minute at 500 volts. A 10 megohm resistance is acceptable.

They shall be tested for correct functioning with their rated supply voltage.

Since purchaser does not always use the heaters, check with purchaser before replacing heaters.

\subsubsection{Vibration Sensors}

Vibration sensors shall be replaced in their original locations.

Where non-contacting proximity sensors or eddy current probes are used, care shall be taken that they are adjusted so they do not touch the shaft.

\subsubsection{Surge Equipment}

Surge capacitors and arresters shall be tested by :

- Testing the capacitors' insulation resistance at 1,000 volts (normally the discharge resistor will give a reading of less than 30 megohm); 
- Applying a DC Hipot test to the arrester at 80 percent of its rating (it should not break down at this level. For a $4.5 \mathrm{kV}$ arrester, the test voltage would be

$$
\text { voltage }=4.5 \times 1.4 \times 0.8=5 \mathrm{kV}) ; \text { and, }
$$

- Alternatively, using a surge tester on the windings with the surge equipment both connected and disconnected (there should be a much less steep wave front with the equipment connected.)

Leaking capacitors, or components which fail the tests shall be replaced.

\subsection{BALANCING}

The motor rotor shall be balanced in a balance stand before assembly of the motor. Balance criteria include the following:

- Half Key It shall be balanced with a half key in the keyway or with sheave or a half coupling and full key.

- Tolerance G2.5 Generally, the permitted total unbalance is $15 \mathrm{~W} / \mathrm{n} / 2=\mathrm{oz}$ in/plane where $\mathrm{W}$ is weight of rotor in pounds and $\mathrm{N}$ is operating speed in RPM. (426 W/n/2 gm. in/plane)

- Tolerance G1.0 Two Pole rotors should be balanced to $6 \mathrm{~W} / \mathrm{n} / 2=$ oz.in./plane. (170.4 W/n/2 gm. in/plane)

- Material Removal If material is removed, structural integrity and fan capacity and efficiency shall be maintained.

- Added Material Added material shall be able to withstand the centrifugal forces and be positioned either in the manufacturer's designated positions and locked in place, or positioned in a location where centrifugal force will tend to keep the material in place. Weights may be attached to metallic parts only.

\subsection{REASSEMBLY}

The assembly of the motor is the reverse of the disassembly process and the following points shall be observed:

- Match marks shaH line up.

- On reinsertion of the rotor, take care not to damage the journals or the stator windings. Cranes, slings and extension pipes shall be used on heavy rotors.

- Dowels and fitted blots shall go back into the same holes that they came from.

- Where they can be measured, all air gaps shall be within 10 percent of the average. 
- On motors with insulated bearings, the insulation shall be checked and noted.

- On vertical motors, the lift on the shaft shall be the same as the original manufacturer's setting, unless purchaser and the repairer agree that a modified setting would give better performance.

- Motors for use in hazardous environments shall have all the explosion-proof features maintained and verified in accord with UL674.

\subsection{FINAL TESTS}

\subsubsection{Insulation}

Prior to running, the motor shall be given an insulation resistance test to ground in the following manner:

- Random Wound For random wound motors, a DC high potential test shall be conducted as specified in NEMA MG1, chapters 3 and 12. Readings corrected to $40^{\circ} \mathrm{C}$, which are less than 100 megohms, shall be discussed with purchaser.

- Form Wound For form wound motors, a polarization index test at 1,000 volts DC for 10 minutes shall be done. Corrected readings less than 500 megohms, or polarization indexes less than two, shall be discussed with purchaser.

- Withstand For form wound motors, a DC withstand test at two times the nominal voltage, plus 1,000 volts, shall be carried out for one minute. Thus, for a 4,000 volt motor, the withstand test shall be 9,000 volts for one minute. Alternatively, an $\mathrm{AC}$ test voltage of 70 percent of the $\mathrm{DC}$ level may be used.

2.18.2 Running Test After the insulation tests, the motor shall be run at no load at full terminal voltage, with either a half key or a half coupling, on the shaft. If the motor uses an external oil supply and removal system in normal use, a similar system shall be arranged for the test. The test shall determine that:

- No Load Amps No load current imbalance at balanced rated voltage shall be less than 2 percent.

- Vibration, Small Motors On motors rated less than $100 \mathrm{HP}$, vibration shall be in conformance with EASA Standard 6.4.6.3 Quality Grade A or other standard provided by purchaser.

- Vibration, Large Motors On motors rated $100 \mathrm{HP}$ and over, hard copy horizontal, vertical and axial readings shall be taken at each bearing and shipped with the report. Tolerance shall not exceed EASA Standard 6.4.6.3 Quality Grade A or other standard provided by purchaser. 
- Temperature Rise Temperature rise after 15 minutes running on motors rated less than $200 \mathrm{HP}$, and one hour or until levels stabilize on larger motors, shall be within normal limits on the frame and bearings. On the larger motors, all final RTD readings shall be recorded.

- Insulated Bearings On motors with insulated bearings, the voltage of the uninsulated bearing shall be checked. If the voltage is more than 0.1 volts, $\mathrm{AC}$ or $\mathrm{DC}$, the bearing insulation shall be rechecked.

- Magnetic Center On motors with sleeve bearings, the magnetic center location shall be verified and oil ring rotation confirmed.

- Shipment At the completion of the test, the motor shall be drained of any oil used for the test, painted and prepared for shipment. Any drained oil sumps shall be marked with a tag advising to refill the sump before operation. Oil and coolant inlets and outlets shall be plugged and masked before painting and shipping.

- Block Shaft Motors shall have their shafts blocked to prevent axial and radial movement during shipping.

\subsection{QUALITY CONTROL}

\subsection{MEASURING INSTRUMENTS}

\subsubsection{Calibration}

3.1.2 Storage

3.2 MATERIALS

\subsubsection{Anti-Friction Bearings}

Anti-friction bearings shall be the same type as originally used, unless otherwise specified by purchaser. In general, only metallic cages shall be used.

Bearings shall be stored in their factory packaging in a clean, dry, vibration free location. 
3.2.2 Solid Insulation Insulating materials such as slot liners, tapes and phase insulation shall be rated for the temperature class of the motor and shall be compatible with the resins used.

Specifications for the materials shall be obtained from the material supplier and kept for checking their suitability for the application.

The materials shall be stored in a clean, dry location. Material such as B stage tape that degrades with time at room temperature, shall be kept refrigerated.

\subsubsection{Resins and Varnishes}

The manufacturer's material specifications for resins and varnishes shall be kept on file, to permit checking for correct storage, handling and usage.

A sample shall have been taken and analyzed to be satisfactory within two months of its being used on a motor.

3.2.4 Other Materials Other materials shall be new and of good quality. In particular the following shall be confirmed:

- Lead Wires Lead wires shall be multi-stranded and flexible with insulation rated for the temperature and voltage class of the motor.

- Magnet Wire Magnet wire for random-wound motors shall be compatible with the other insulation system components and shall be insulated with a polyamide, polyimide or a combination of both, over a polyester base coat, or equivalent. Any wire damaged in storage or working shall be replaced. The manufacturer's specifications for the insulation shall be kept on file for reference.

- Formed Coils All the formed coil supplier's quality assurance data shall be supplied with the coils and shall be included with the quality record for the motor.

\subsection{TESTS AND INSPECTION DURING WORK}

3.3.1 Records

3.3.2 Access
Records shall be kept of all tests and inspections carried out during the work. Signed copies of these records shall be shipped in original form, at the same time as the motor, to the purchaser's designated contact person.

Purchaser shall have access to the repair facilities at all times that work is being done, for the purposes of checking progress and inspecting the work.

\subsection{FINAL INSPECTION AND TEST}

For all motors over $200 \mathrm{HP}$, and other critical motors, purchaser shall be informed when the final inspection and testing of the motor is to take place. Purchaser shall have the right to be present for tests on any motors. 
In emergency cases; tests will not be held up waiting for purchaser representatives, but every effort shall be made to keep purchaser informed so that they can be present if possible.

All final inspection and test results shall be sent, in their original form, to the designated contact person.

\subsection{PERSONNEL}

3.5.1 Employees

Employees shall be trained and experienced to the level required for the work being done.

\subsection{DOCUMENTATION}

\subsection{PURCHASER MOTOR REPAIR FORM}

A Motor Repair Form is attached in Appendix A. One of these forms will normally accompany each motor sent out for repair.

\subsection{REPAIRER'S QUALITY RECORD}

A sample Repairer's Quality Record Form is attached in Appendix B. Either this form, or the repairer's approved equivalent form, shall be used on each motor.

\subsection{REPAIR SHOP EVALUATION}

\subsection{INSPECTION}

\subsubsection{General}

5.1.2 Factors
All repair shops doing business with purchaser will be inspected and evaluated. The results of the evaluation will determine what type and rating of motor will be sent to particular shops.

The results of the evaluation will be discussed with each shop, if desired.

The factors in the evaluation will be:

- Capacity and condition of lifting equipment;

- Winding and insulation equipment and tools;

- Mechanical capabilities;

- Technical capabilities and backup;

- Quantity and quality of test equipment;

- Shop cleanliness;

- Record keeping; and,

- The proportion and type of work sent to subcontractors, and the abilities of the subcontractors to meet the above factors. 
Appendix A

\section{Motor Repair Form}





\section{Motor Repair Form (page 1 of 1)}

Repairer:

Motor Designation:

Manufacturer:

Volts:

Serial \#:

Other:

Service:

\section{Date:}

Site:

Type:

Power:

Speed:

Frame:

Bearings:

Lubricant Grade:

\section{Reason sent for}

repair:

Required work:

Past problems with machine:

Contamination $\mathrm{H}_{2} \mathrm{~S}(\mathrm{)}$

Other (specify)

\section{Past problems with machine:}

Missing parts:

Urgency: (check one)

Rush, full O.T.

$\square$ Rush, limited O.T.

$\square$ ASAP, no O.T.

$\square$ Routine (specify time)

$\square$ Hold points if required

\section{Cost limitations:}

Contact with price before work

$\square$ Go ahead, advise price

$\square$ Other

Special instructions

Contact:

Phone:

Reference: 



\section{Appendix B}

Repairer's Quality Record 


\section{Repairer's Quality Record - Induction Motor \\ (Attach other notes and test results as needed) \\ (page 1 of 3 )}

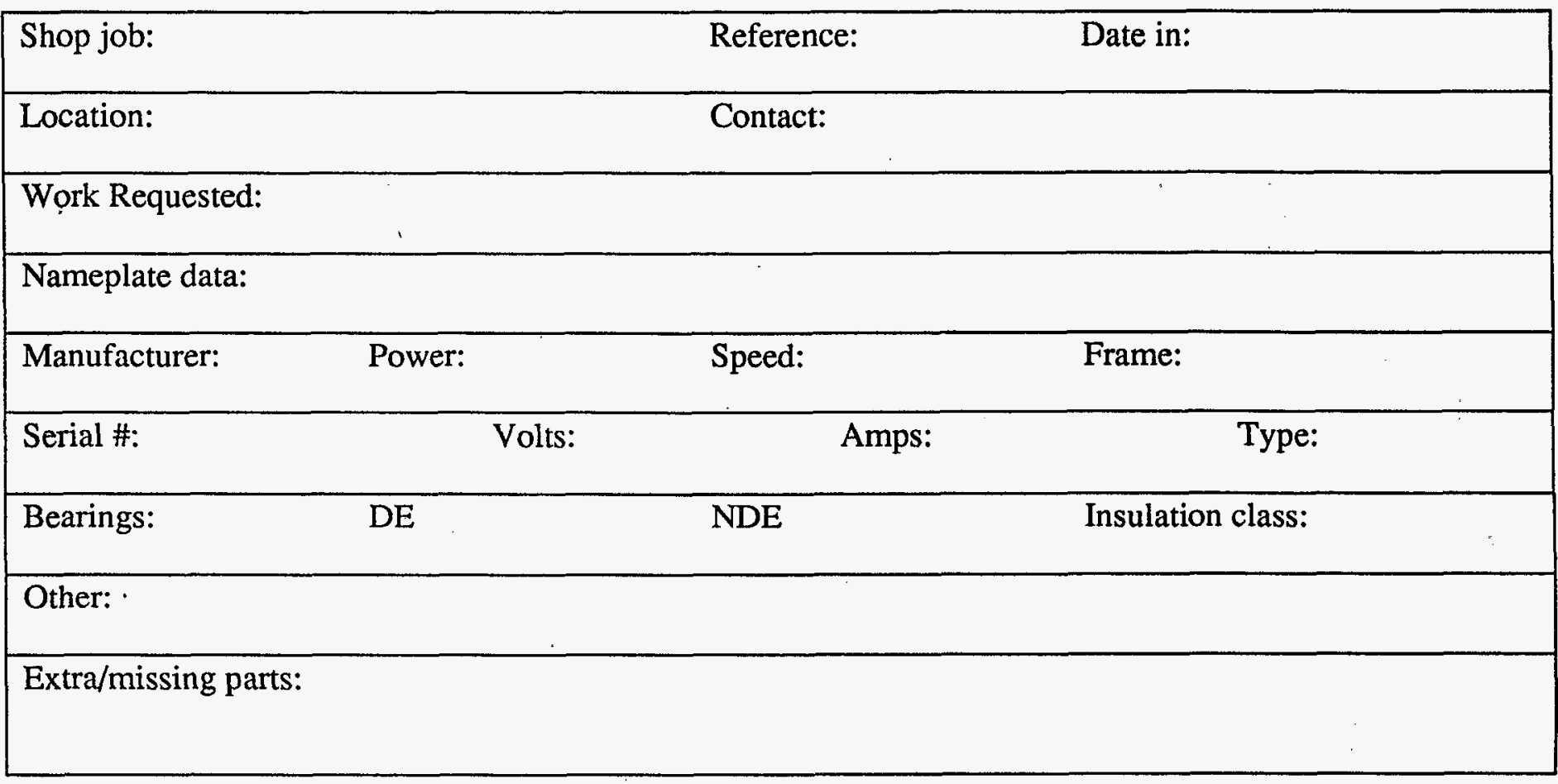

INCOMING TEST

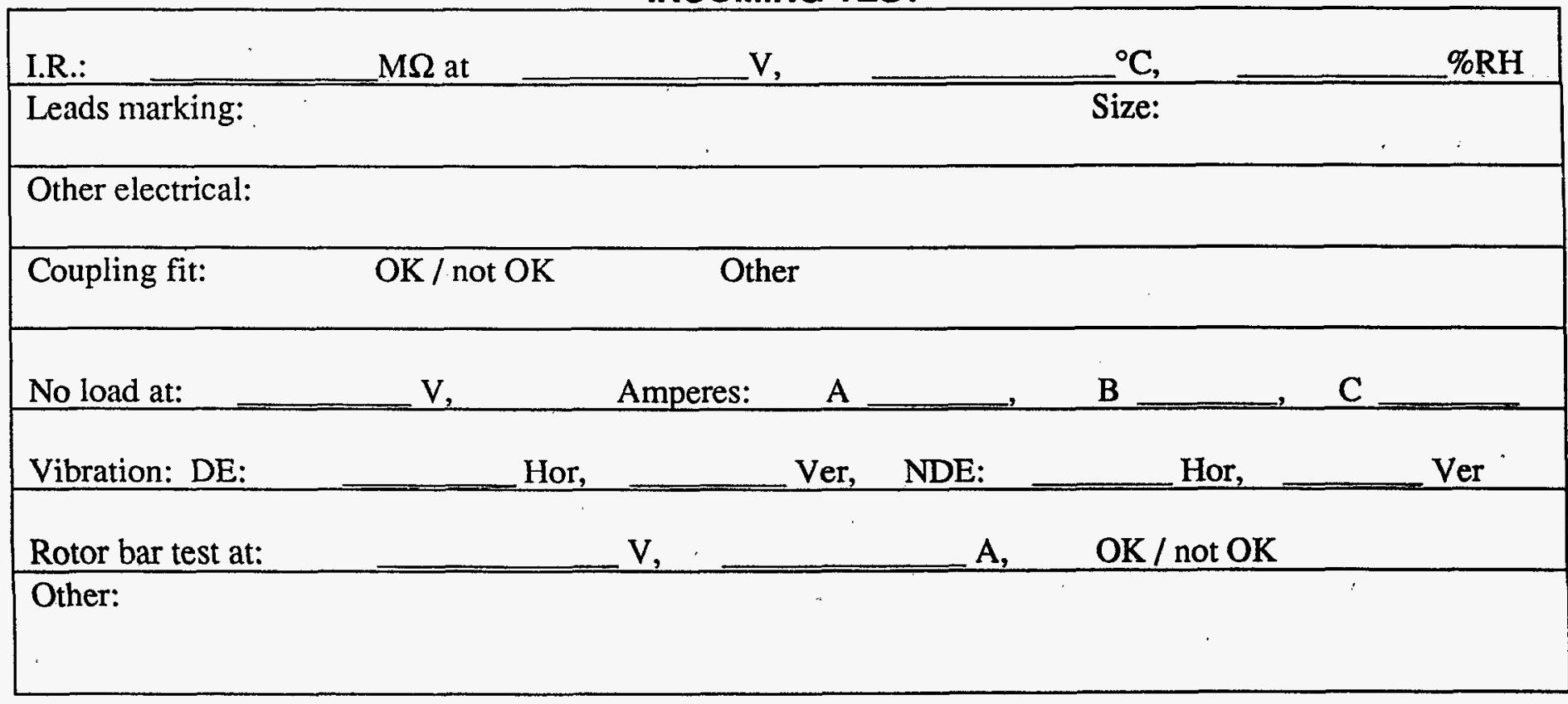




\section{Repairer's Quality Record - Induction Motor \\ (Attach other notes and test results as needed) \\ (page 2 of 3 )}

\begin{tabular}{|lll|}
\hline Shop job: & Reference: & Date in: \\
\hline Location: & Contact: & \\
\hline
\end{tabular}

\section{DISMANTLED}

\begin{tabular}{|c|c|c|c|}
\hline Surge test at: & $\mathrm{OK} /$ not $\mathrm{OK}$ & & \\
\hline $\begin{array}{l}\text { Core loss tests at: } \\
\text { (attach detailed results) }\end{array}$ & $\begin{array}{l}\text { Before strip } \\
\text { After strip }\end{array}$ & $\begin{array}{r}\mathrm{W} / \mathrm{kg}, \\
\mathrm{W} / \mathrm{kg},\end{array}$ & $\begin{array}{r}\text { Hot spots } \mathrm{Y} / \mathrm{N} \\
\text { Hot spots } \mathrm{Y} / \mathrm{N}\end{array}$ \\
\hline Bearing fits: & & $\mathrm{DE}$ & $\mathrm{NDE}$ \\
\hline \multicolumn{4}{|l|}{ Journal } \\
\hline Housing & & & \\
\hline Bearing race pitting from shaft currents & $\mathrm{DE}$ & $\mathrm{Y} / \mathrm{N}$ & $\mathrm{NDE}$ \\
\hline
\end{tabular}

\section{WINDING DETAILS}

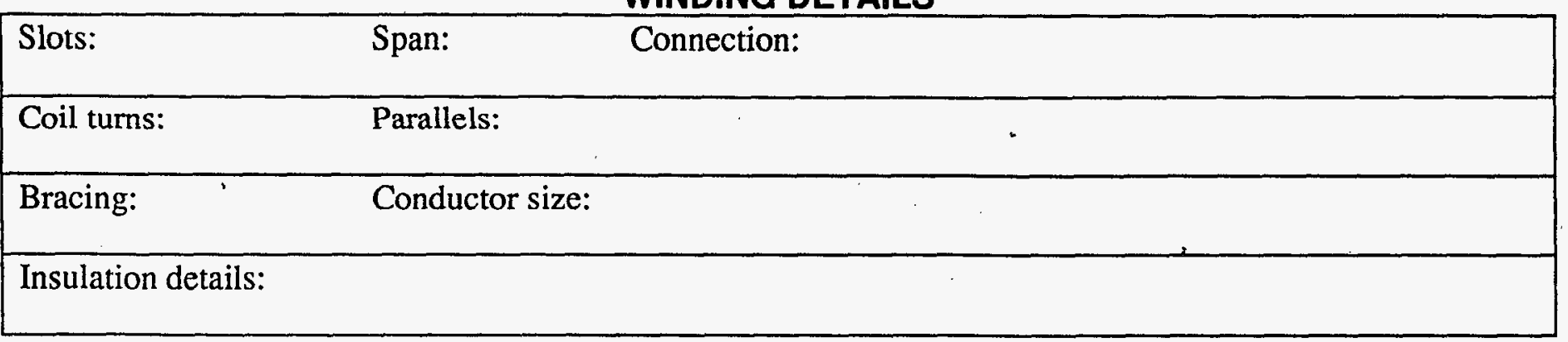

\section{REWINDS}

Surge test at: $\mathrm{V}, \quad \mathrm{Ok} / \mathrm{not} \mathrm{OK}$

HiPot/megger at: $\mathrm{V}$, minutes, leakage/IR

Coil bracing:

Resin last tested:

Bake temp:

${ }^{\circ} \mathrm{C}$ hours

VPI: Vacuum $\mathrm{mm}$,

Pressure $\mathrm{kPa}$

Cycle time: hours

Cycle time: hours 


\section{Repairer's Quality Record - Induction Motor \\ (Attach other notes and test results as needed) \\ (page 3 of 3 )}

\begin{tabular}{|c|c|c|c|c|}
\hline Shop job: & & Refere & & Date in: \\
\hline Location: & & Contac & & \\
\hline & & & R REPAIF & DETAILS \\
\hline SHAFT REPAIR WOR & $\mathrm{DE}$ & NDE & $\begin{array}{l}\text { Specified } \\
\text { Figure }\end{array}$ & Fan: \\
\hline TIR at coupling & & & & Coupling/Keyway: \\
\hline Journal diameter & & & & \\
\hline $\mathrm{A} / \mathrm{F}$ bearing type & & & & \\
\hline Fit to shaft & & & & \\
\hline Fit to housing & & & & Balance to: \\
\hline $\begin{array}{l}\text { Sleeve bearing: } \\
\text { Journal clearance }\end{array}$ & & & & \\
\hline Housing clearance & & & & \\
\hline
\end{tabular}

\section{OTHER WORK}

Final Test

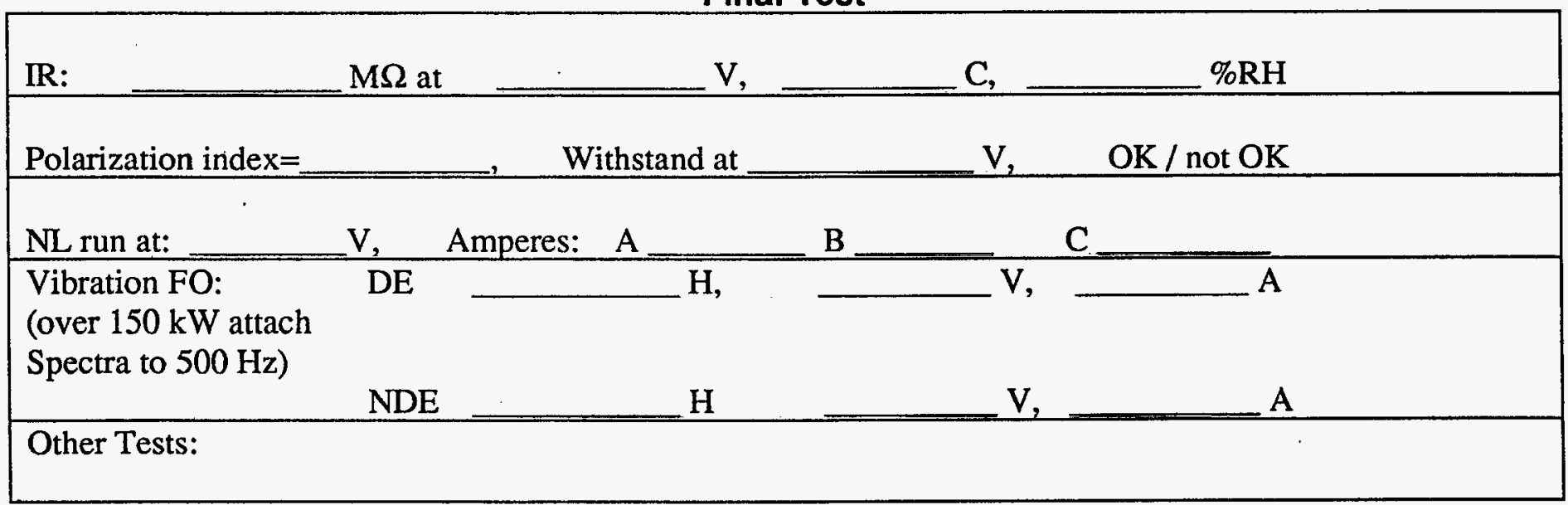

Tested by:

Date shipped:

Carrier:

Additional notes: 


\section{Appendix C}

\section{Winding Temperature Correction}


Temperature Coefficient

$\mathrm{K} 1$

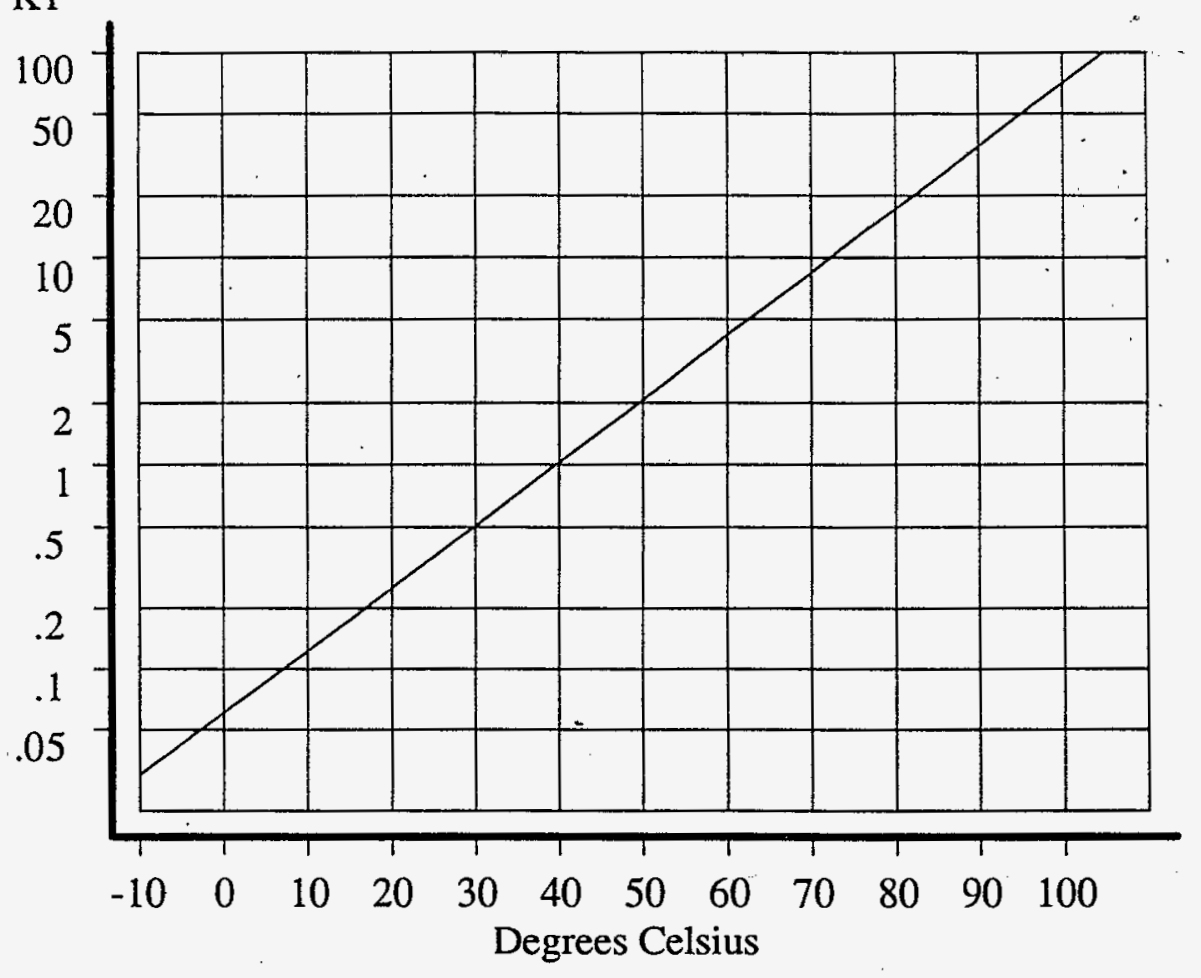

To Convert Observed Insulation Resistance (R1) to 40C. multiply by the temperature coefficient, $\mathrm{K} 1 . \mathrm{Rc}=\mathrm{R} 1 * \mathrm{~K} 1$

Figure C-1 Winding Temperature in Degrees Celsius. 


\section{DISCLAIMER}

This report was prepared as an account of work sponsored by an agency of the United States Government. Neither the United States Government nor any agency thereof, nor any of their employees, makes any warranty, express or implied, or assumes any legal liability or responsibility for the accuracy, completeness, or usefulness of any information, apparatus, product, or process disclosed, or represents that its use would not infringe privately owned rights. Reference herein to any specific commercial product, process, or service by trade name, trademark, manufacturer, or otherwise does not necessarily constitute or imply its endorsement, recommendation, or favoring by the United States Government or any agency thereof. The views and opinions of authors expressed herein do not necessarily state or reflect those of the United States Government or any agency thereof. 